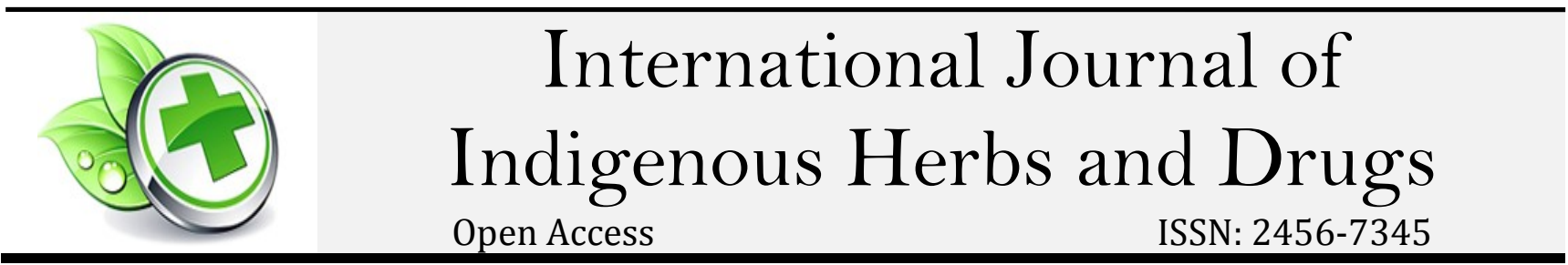

\title{
Formulation development and evaluation of luliconazole topical emulgel
}

K. Naga sai divya, T Malyadri, Ch.saibabu

1 Department of Pharmaceutics, M.L. College of Pharmacy, S. Konda-523101

2 Assistant professor, Department of Pharmaceutics, M.L. College of Pharmacy, S. Konda-523101

3 Head, Department of Pharmaceutics, M.L. College of Pharmacy, S. Konda-523101

\begin{tabular}{ll}
\hline Article Info : & Abstract \\
\hline $\begin{array}{l}\text { Article History } \\
\text { Received on: 28-04-2021 }\end{array}$ & $\begin{array}{l}\text { The purpose of the present study was to develop and optimize the emulgel system for } \\
\text { Luliconazole using different types of gelling agents: HPMCK15M, Carbopol 940, and Xanthan } \\
\text { Revised on : 13-05-2021 } \\
\text { Accepted on : 08-06-2021 }\end{array}$ \\
\hline & $\begin{array}{l}\text { Giscosity, drug content, and in-vitro drug release. In-vitro release study demonstrated } \\
\text { diffusion-controlled release of Luliconazole from formulation up to 12 hours. The drug } \\
\text { release profile exhibited zero-order kinetics. All the prepared emulgels showed acceptable } \\
\text { physical properties concerning color, homogeneity, consistency, spreadability, and higher } \\
\text { drug release. In the case of all evaluation parameters, carbopol based formulation showed } \\
\text { better properties so, as a general conclusion, it was suggested that the Luliconazole emulgel } \\
\text { formulation prepared with carbopol (F6) was the formula of choice. } \\
\text { Keywords: Luliconazole, Carbopol 940, Xanthan Gum, HPMC K15M. }\end{array}$ \\
&
\end{tabular}

This article is licensed under a Creative Commons Attribution-Non Commercial 4.0 International License. Copyright (C) 2021 Author(s) retain the copyright of this article.

\section{*Corresponding Author \\ K. Naga sai divya}

Doi: https://doi.org/10.46956/ijihd.vi.163

\section{Production and Hosted By}

Saap.org.in

\section{Introduction}

Topical formulations apply a wide spectrum of preparations both cosmetic and dermatological, to healthy or diseased skin [1]. These formulations range in consistency from solid through semisolid to liquids. When gels and emulsions are used in a combined form, the dosage forms are referred to emulgel. [2, 3]As the name suggests they are the combination of emulsion microemulsion and gel. Novel polymers with complex functions as emulsifiers and thickeners have been widely used due to their gelling capacity which allows the formulation of stable emulsion by decreasing surface and interfacial tension and also by increasing the viscosity of the aqueous phase. Oil/water and water/oil emulsions are used as vehicles to deliver various drugs to the skin [4]. Emulsion gels are has importance due to many reasons; they have better application property in comparison to classical formulation as creams and ointment, they have faster and more complete release of the drug from the vehicle to the skin, also they are convenient to apply on hairy skin due to the absence of greasiness and lack of residue upon application. They permit the incorporation of both aqueous and oleaginous ingredients, so hydrophobic or poorly water soluble drugs as antifungal agents are easily incorporated in such type of vehicles through the proper choice of the oily phase [5].<smiles>N#CC(=C1SC[C@H](c2ccc(Cl)cc2Cl)S1)n1ccnc1</smiles>

Fig 01: chemical structure of Luliconazole Luliconazole has anti-fungal activity. Luliconazole is inhibiting the enzyme lanosterol demethylase. Lanosterol demethylase is needed for the synthesis of ergo-sterol, which is a major component of the fungus cell membranes. For skin care and the topical treatment of dermatological diseases, a wide choice of vehicles including solid, semisolids and liquid Preparation is available to physician and patients. Within the major groups of semisolid preparations, the use of transparent emulgel has expanded, both in cosmetics and pharmaceuticals. Emulgel or jellified emulsion is stable one and better vehicle for 
hydrophobic or water insoluble drugs as Luliconazole. Also, emulgel has a high patient acceptability since they possess the advantages of both emulsions and gels. Therefore, they have been recently used as vehicles to deliver various drugs to the skin. [6-7]

\section{Materials}

Luliconazole from BMR Chemicals, Hyderabad ,HPMC K15M Color cone Asia Ltd., Verna, Goa. Carbapol 940 , Xanthan gum , Tween 20, Span 20 from MJ Biopharmaceuticals, Mumbai, Benzalkonium chloride, Methanol, SD Fine Chemicals.

\section{Methodology}

\section{Solubility studies}

Solubility of Luliconazole was carried out in different solvents like Methanol, Ethanol, 0.1N HCL, and 6.8and 7.4 pH buffer. Saturated solutions were prepared by adding excess drug to the vehicles and shaking on the shaker for $24 \mathrm{hrs}$ at $25^{\circ} \mathrm{C}$ under constant vibration. Filtered samples $(1 \mathrm{ml})$ were diluted appropriately with suitable buffer and solubility of Luliconazole was determined spectrophotometrically at $297 \mathrm{~nm}$.

a) Physical mixtures of drug and excipients were prepared by grinding specific ratios of drug and excipients in a mortar. Sample of 3-4 grams was loaded in a glass vial, covered with rubber stopper, sealed with aluminum cap and labeled properly. Samples were observed and color was recorded for initial evaluation and loaded into stability chambered at $40^{\circ} \mathrm{c}$ temperature and $75 \%$ relative humidity for 30 days to study the Compatibility study. Samples were removed after 15 days and 30 days and observed for any change in the color.

b) FTIR spectroscopy

The physical compatibility between the pure drug and polymers used in the research was tested by Infra Red (IR) spectroscopy. FTIR absorption spectra for pure drug and physical mixture were recorded in the range of $400-4000 \mathrm{~cm}^{-1}$ by $\mathrm{KBr}$ disc method using FTIR spectrophotometer.

Determination of Absorption maxima by UV spectrophotometer

Solution of drug were prepared in $7.4 \mathrm{pH}$ buffer and scanned in the range of 200 to $400 \mathrm{~nm}$ using PG INSTRUMENTS UV spectrophotometer of (model No.T60), in order to determine the absorption maxima for analysis of dissolution samples.

Preparation of calibration curve of Luliconazole $10 \mathrm{mg}$ of Luliconazole was dissolved in $10 \mathrm{ml}$ of methanol by slight shaking $(1000 \mathrm{mcg} / \mathrm{ml}) .1 \mathrm{ml}$ of this solution was taken and made up to $10 \mathrm{ml}$ with $7.4 \mathrm{pH}$ buffer, which gives $100 \mathrm{mcg} / \mathrm{ml}$ concentration (stock solution). From the stock solution, concentrations of $5,10,15,20,25$ and $30 \mu \mathrm{g} / \mathrm{ml}$ in $7.4 \mathrm{pH}$ buffer were prepared. The absorbance of diluted solutions was measured at $297 \mathrm{~nm}$ and a standard plot was drawn using the data obtained. The correlation coefficient was calculated.
Method of Preparation of Luliconazole emulgels [8-14] Luliconazole emulgels were prepared using compositions given in Table. Take $100 \mathrm{ml}$ beaker, in that beaker take HPMC K4M and then mix with $40 \mathrm{ml}$ distilled water, now heat the mixture at $60^{\circ} \mathrm{C}$ till solution occurs using a heating magnetic stirrer (Gelling phase).Take another beaker, in this add Span 20 along with liquid paraffin and kept aside. Then take another beaker and add Tween 20 and water, benzalkonium chloride and propylene glycol and kept aside. Now take another beaker, add $5 \mathrm{ml}$ of methanol with drug, then add all the three mixtures are mixed at $60^{\circ} \mathrm{C}$. Then add this final mixture to the gelling phase, and stirred for 30 mins and kept aside for cooling for the formation of emulgels.

Table 01 - Formulation table of Luliconazole emulgels

\begin{tabular}{|c|c|c|c|c|c|c|c|c|c|}
\hline $\begin{array}{c}\text { Ingredi } \\
\text { ents }\end{array}$ & $\begin{array}{l}\mathbf{F} \\
1\end{array}$ & $\begin{array}{l}F \\
2\end{array}$ & $\begin{array}{l}\mathbf{F} \\
3\end{array}$ & $\begin{array}{l}F \\
4\end{array}$ & $\begin{array}{l}\mathbf{F} \\
5\end{array}$ & $\begin{array}{l}F \\
6\end{array}$ & $\begin{array}{l}F \\
7\end{array}$ & $\begin{array}{l}\mathbf{F} \\
8\end{array}$ & $\begin{array}{l}\mathbf{F} \\
9\end{array}$ \\
\hline $\begin{array}{c}\text { Lulicona } \\
\text { zole } \\
(\% \\
w / w)\end{array}$ & 1 & 1 & 1 & 1 & 1 & 1 & 1 & 1 & 1 \\
\hline $\begin{array}{l}\text { HPMC } \\
\text { K15M }\end{array}$ & $\begin{array}{l}0 . \\
5\end{array}$ & - & - & $\begin{array}{c}0 . \\
75\end{array}$ & - & - & 1 & - & - \\
\hline $\begin{array}{c}\text { Xanthan } \\
\text { gum }\end{array}$ & - & $\begin{array}{l}0 . \\
5\end{array}$ & - & - & $\begin{array}{c}0 . \\
75\end{array}$ & - & - & 1 & - \\
\hline $\begin{array}{c}\text { Carbapo } \\
1940\end{array}$ & - & - & $\begin{array}{l}0 . \\
5\end{array}$ & - & - & $\begin{array}{c}0 . \\
75\end{array}$ & - & - & 1 \\
\hline $\begin{array}{c}\text { Tween } \\
20\end{array}$ & $\begin{array}{l}0 . \\
3\end{array}$ & $\begin{array}{l}0 . \\
3\end{array}$ & $\begin{array}{l}0 . \\
3\end{array}$ & $\begin{array}{l}0 . \\
3\end{array}$ & $\begin{array}{l}0 . \\
3\end{array}$ & $\begin{array}{l}0 . \\
3\end{array}$ & $\begin{array}{l}0 . \\
3\end{array}$ & $\begin{array}{l}0 . \\
3\end{array}$ & $\begin{array}{l}0 . \\
3\end{array}$ \\
\hline Span 20 & $\begin{array}{l}0 . \\
5\end{array}$ & $\begin{array}{l}0 . \\
5\end{array}$ & $\begin{array}{l}0 . \\
5\end{array}$ & $\begin{array}{l}0 . \\
5\end{array}$ & $\begin{array}{l}0 . \\
5\end{array}$ & $\begin{array}{l}0 . \\
5\end{array}$ & $\begin{array}{l}0 . \\
5\end{array}$ & $\begin{array}{l}0 . \\
5\end{array}$ & $\begin{array}{l}0 . \\
5\end{array}$ \\
\hline $\begin{array}{c}\text { Benzalk } \\
\text { onium } \\
\text { chloride }\end{array}$ & $\begin{array}{l}0 . \\
01\end{array}$ & $\begin{array}{c}0 . \\
01\end{array}$ & $\begin{array}{l}0 . \\
01\end{array}$ & $\begin{array}{l}0 . \\
01\end{array}$ & $\begin{array}{c}0 . \\
01\end{array}$ & $\begin{array}{l}0 . \\
01\end{array}$ & $\begin{array}{c}0 . \\
01\end{array}$ & $\begin{array}{c}0 . \\
01\end{array}$ & $\begin{array}{c}0 . \\
01\end{array}$ \\
\hline $\begin{array}{c}\text { Light } \\
\text { liquid } \\
\text { paraffin( } \\
\text { ml) }\end{array}$ & 5 & 5 & 5 & 5 & 5 & 5 & 5 & 5 & 5 \\
\hline $\begin{array}{c}\text { Methano } \\
\text { l (ml) }\end{array}$ & 5 & 5 & 5 & 5 & 5 & 5 & 5 & 5 & 5 \\
\hline Water & 50 & 50 & 50 & 50 & 50 & 50 & 50 & 50 & 50 \\
\hline
\end{tabular}

Evaluation parameters of emulgels [15-18]

Visual Appearance and Clarity

Visual appearance and Clarity was done under fluorescent light against a white and black back ground for presence of any particulate matter.

\section{pH Measurement}

The $\mathrm{pH}$ of the prepared in-situ gelling system after addition of all the ingredients was measured using $\mathrm{pH}$ meter.

\section{Determination of drug content}

Accurately $10 \mathrm{ml}$ of formulation from different batches was measured and transferred to $100 \mathrm{ml}$ volumetric flask. To this $50-70 \mathrm{~mL}$ of $7.4 \mathrm{pH}$ buffer was added and sonicated for $30 \mathrm{~min}$. Volume was adjusted to $100 \mathrm{~mL}$. Complete 
dispersion of contents was ensured visually and the dispersion was filtered using Whattman Filter Paper. From this solution, $10 \mathrm{ml}$ of sample was withdrawn and diluted to $100 \mathrm{ml}$ with $7.4 \mathrm{pH}$ buffer. Contents of Luliconazole was measured at maximum absorbance at $248 \mathrm{~nm}$ using UV-Visible Spectrophotometer (PG INSTRUMENTS,T60,].

\section{Spreadability}

Spreadability is determined by apparatus suggested by Mutimer et al (1956) which is suitably modified in the laboratory and used for the study. It consists of a wooden block, which is provided by a pulley at one end. By this method, spreadability is measured on the basis of 'Slip' and 'Drag' characteristics of emulgels. A ground glass slide is fixed on this block. An excess of emulgel (about $2 \mathrm{gm}$ ) under study is placed on this ground slide. The emulgel is then sandwiched between this slide and another glass slide having the dimension of fixed ground slide and provided with the hook. A $1 \mathrm{Kg}$ weight is placed on the top of the two slides for 5 minutes to expel air and to provide a uniform film of the emulgel between the slides. Excess of the emulgel is scrapped off from the edges. The top plate is then subjected to pull of 80 gms. With the help of string attached to the hook and the time (in seconds) required by the top slide to cover a distance of $7.5 \mathrm{~cm}$ be noted. A shorter interval indicate better spreadability. Spreadability was calculated by using the formula,

$$
\mathrm{S}=\mathrm{M} . \mathrm{L} / \mathrm{T}
$$

Where, $\mathrm{S}=$ spreadability,

$\mathrm{M}=$ Weight tied to upper slide,

$\mathrm{L}=$ Length of glass slides

$\mathrm{T}=$ Time taken to separate the slides

completely from each other.

\section{Measurement of viscosity of Emulgels}

Viscosity of the dispersion was determined using a Brookfield digital viscometer (NDJ-5S Viscometer). The samples $(200 \mathrm{~mL})$ were sheared at a rate of $100 \mathrm{rpm} / \mathrm{min}$ using spindle number 2 at room temperature. Viscosity measurement for each sample was done in triplicate, with each measurement taking approximately 30 seconds.

\section{In-Vitro Release Studies}

In vitro drug release studies were carried out by putting the formulation on Millipore membrane filter $(0.15 \mathrm{~mm})$ between the donor and receptor compartments of an allglass modified Franz diffusion cell. The receptor compartment of an all-glass modified Franz diffusion cell was filled with $40 \mathrm{~mL}$ freshly prepared $7.4 \mathrm{pH}$, and all air bubbles were expelled from the compartment. An aliquot $(1 \mathrm{~mL})$ of test solution was placed on the Millipore membrane filter, and the opening of the donor cell was sealed with a glass cover slip. The receptor fluid was kept at $37 \pm 0.5^{\circ} \mathrm{C}$ with constant stirring using a Teflon-coated magnetic stir bead. Permeation study was continued for $12 \mathrm{hr}$, and samples were withdrawn from receptor and analyzed for Luliconazole content by measuring absorbance at $248 \mathrm{~nm}$ in a spectrophotometer.

\section{Kinetic Studies Mathematical models [19-20]}

Different release kinetic equations (zero-order, first-order, Higuchi's equation and Korsmeyer-peppas equation) were applied to interpret the release rate of the drug from matrix systems for the optimized formulation. The best fit with higher correlation $\left(\mathrm{r}_{2}\right)$ was calculated.

\section{Zero-order model}

Drug dissolution from dosage forms that do notdisaggregate and release the drug slowly can be representedby the equation

$$
\mathbf{Q t}=\mathbf{Q 0}+\mathbf{K O t}
$$

Where Qt is the amount of drug dissolved in time $t, \mathrm{Q} 0$ is the initial amount of drug in the solution (most times, $\mathrm{Q} 0=$ 0 ) and $\mathrm{K} 0$ is the zero order release constant expressed in units of concentration/time. To study the release kinetics, data obtainedfrom in vitro drug release studies were plotted as cumulative amount of drug released versustime.

\section{Application}

It is used to describe the drug dissolution of several types of modified release pharmaceutical dosage forms, as in the case of some transdermal systems, as well as tablets with low soluble drugs in coated forms, osmotic systems, etc.

\section{First Order Model}

The first order equation describes the release from systems where the dissolution rate is dependent upon the concentration of the dissolving species.

Release behavior generally follows the following first order equation:

$$
\log C=\log C_{o}-k t / 2.303
$$

Where $\mathrm{C}$ is the amount of drug dissolved at time $\mathrm{t}$, $\mathrm{C}_{\mathrm{o}}$ is the amount of drug dissolved at $\mathrm{t}=0$ and $\mathrm{k}$ is the first order rate constant.

\section{A graph of log cumulative of \% drug remaining vs time} yields a straight line

The pharmaceutical dosage forms following this dissolution profile, such as those containing water-soluble drugs in porous matrices, release the drugs in a way that is proportional to the amount of drug remaining in its interior, in such way, that the amount of drug released by unit of time diminishes.

\section{Higuchi model}

The first example of a mathematical model aimed to describe drug release from a system was proposed by Higuchi in 1961. Initially conceived for planar systems, it was then sustained to different geometrics and porous systems. This model is based on the hypothesis that

- initial drug concentration in the is much higher than drug solubility;

- drug diffusion takes place only in one dimension (edge effect must be negligible);

- drug particles are much smaller than system thickness;

- $\quad$ swelling and dissolution are negligible;

- drug diffusivity is constant; and 
- Perfect sink conditions are always attained in the release environment.

In a general way the Higuchi model is simply expressed by following equation

$$
\mathbf{Q}=K_{H}-\mathbf{t}^{\mathbf{1} / \mathbf{2}}
$$

Where, $\mathrm{K}_{\mathrm{H}}$ is the Higuchi dissolution constant.

The data obtained were plotted as cumulative percentage drug release versus square root of time.

\section{Application}

This relationship can be used to describe the drug dissolution from several types of modified release pharmaceutical dosage forms, as in the case of some transdermal systems and tablets with water soluble drugs.

\section{Korsmeyer-Peppas model}

Korsmeyer et al.(1983) derived a simple relationship which described drug release from a polymeric system equation. To find out the mechanism of drug release, first60\% drug release data were fitted in KorsmeyerPeppas model,

$$
\text { Mt } / \mathbf{M} \infty=\mathbf{K t}^{\mathbf{n}}
$$

where $\mathrm{Mt} / \mathrm{M} \infty$ is a fraction of drug released at time $t, k$ is the release rate constant and $\mathrm{n}$ is the release exponent. The $\mathrm{n}$ value is used to characterize different release for cylindrical shaped matrices. In this model, the value of $n$ characterizes the release mechanism of drug as described in the following table.

Table 02: Drug transport mechanisms suggested

\begin{tabular}{|c|c|c|c|}
\hline $\begin{array}{l}\text { S. } \\
\text { No }\end{array}$ & $\begin{array}{c}\text { Release } \\
\text { exponent }\end{array}$ & $\begin{array}{c}\text { Drug } \\
\text { transport } \\
\text { mechanism }\end{array}$ & $\begin{array}{l}\text { Rate as a } \\
\text { function of } \\
\text { time }\end{array}$ \\
\hline 1 & 0.5 & Fickian diffusion & $t^{-0.5}$ \\
\hline 2 & $\begin{array}{c}0.45<\mathrm{n}= \\
0.89\end{array}$ & $\begin{array}{c}\text { Non -Fickian } \\
\text { transport }\end{array}$ & $t^{n-1}$ \\
\hline 3 & 0.89 & $\begin{array}{l}\text { Case II } \\
\text { transport }\end{array}$ & $\begin{array}{l}\text { Zero order } \\
\text { release }\end{array}$ \\
\hline 4 & $\begin{array}{c}\text { Higher than } \\
0.89\end{array}$ & $\begin{array}{c}\text { Super case II } \\
\text { transport }\end{array}$ & $\mathrm{t}^{\mathrm{n}-1}$ \\
\hline
\end{tabular}
based on ' $n$ ' value

To find out the exponent of $n$ the portion of the release curve, where Mt $/ \mathrm{M} \infty<0.6$ should only be used. To study the release kinetics, data obtained from in vitro drug release studies were plotted as log cumulative percentage drug release versus log time.

\section{Results and dissuasion}

\section{Saturation Solubility of Luliconazole}

Solubility of Luliconazole was determined in Methanol, Ethanol, $0.1 \mathrm{~N} \mathrm{HCL}, \& 6.8$ and $7.4 \mathrm{pH}$ phosphate buffer and values obtained were noted in the table given below Table 03: Solubility studies

\begin{tabular}{|c|c|}
\hline Solvents & $\begin{array}{l}\text { Solubility } \\
(\mathrm{mg} / \mathrm{mL})\end{array}$ \\
\hline
\end{tabular}

\begin{tabular}{|c|c|}
\hline Ethanol & 4.11 \\
\hline Methanol & 7.02 \\
\hline $0.1 \mathrm{~N} \mathrm{HCL}$ & 1.04 \\
\hline $6.8 \mathrm{PH}$ Buffer & 0.978 \\
\hline $7.4 \mathrm{pH} \mathrm{Buffer}$ & 1.684 \\
\hline
\end{tabular}

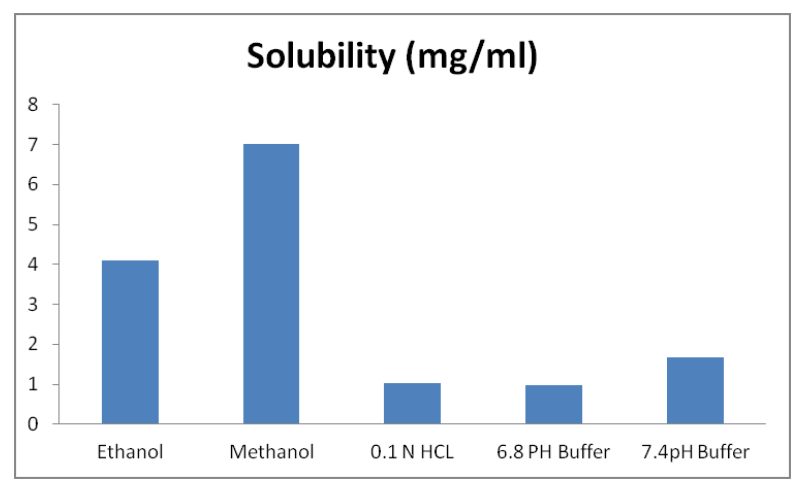

Fig 02: solubility chart in different solvents

From the above solubility data we can say that Luliconazole has more solubility in7.4pH buffer among the buffers.

\section{Compatibility study of Luliconazole}

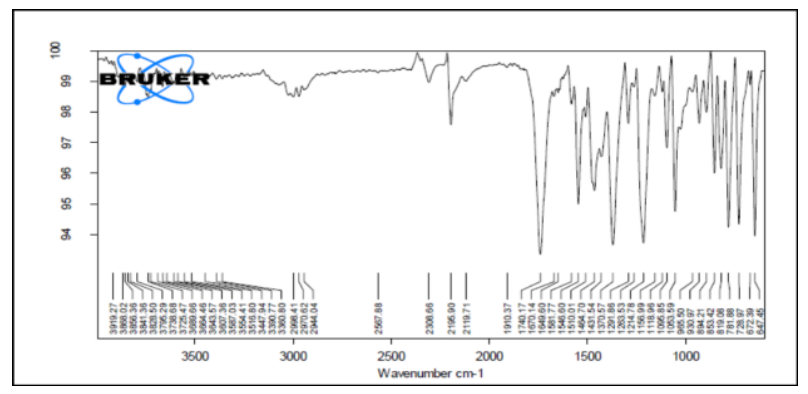

Fig 03: FTIR graph of pure Luliconazole

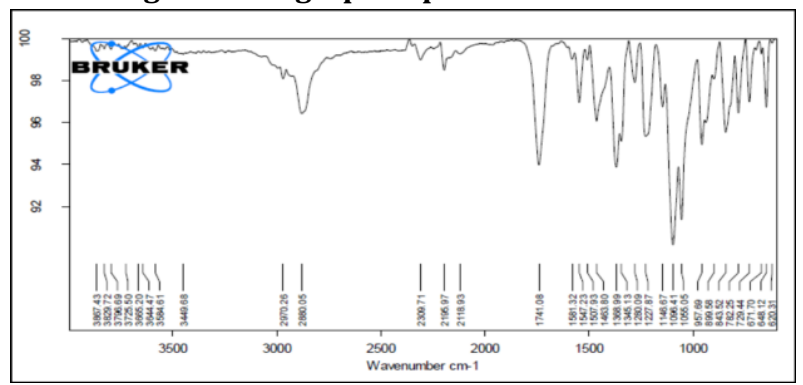

Fig 04: FTIR graph of optimized formulation

Compatibility between the drug and polymers was studied by FT-IR method. Pure Luliconazole and optimized formulation were subjected for FT-IR spectroscopic analysis, to ascertain any interaction between the drug and polymers used. The position of characteristic peaks of pure Luliconazole was compared with those peaks obtained for optimized formulation. These characteristic bands for Luliconazole were identifiable and there was no 
major shift or disappearance in the peak positions. This indicated that the drug was intact and has not reacted with the excipients used in the formulation and hence they are compatible. Hence, it can be concluded that the drug is in free-state and can release easily from the polymeric network in the free form.

Determination of absorption maximum ( $\lambda \max$ ) of Luliconazole

Determination of Luliconazole $\lambda$-max was done for accurate quantitative assessment of drug dissolution rate.

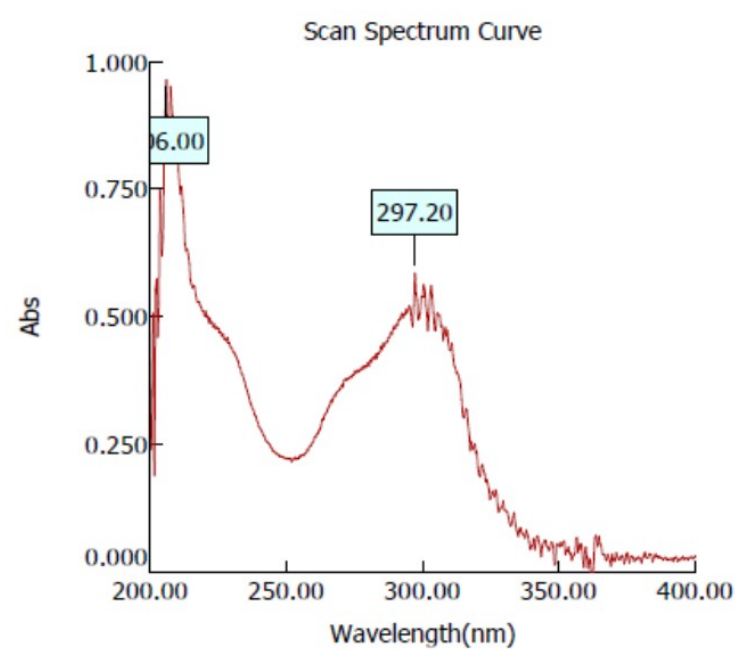

Fig 05: Absorption maximum ( $\lambda$ max) of Luliconazole Standard calibration curve of Luliconazole Table 04: Calibration curve data of Luliconazole

\begin{tabular}{|c|c|}
\hline $\begin{array}{c}\text { Concnetration } \\
(\boldsymbol{\mu g} / \mathbf{m l})\end{array}$ & Absorbance \\
\hline 0 & 0 \\
\hline 2 & 0.116 \\
\hline 4 & 0.246 \\
\hline 6 & 0.351 \\
\hline 8 & 0.469 \\
\hline 10 & 0.587 \\
\hline 12 & 0.706 \\
\hline
\end{tabular}

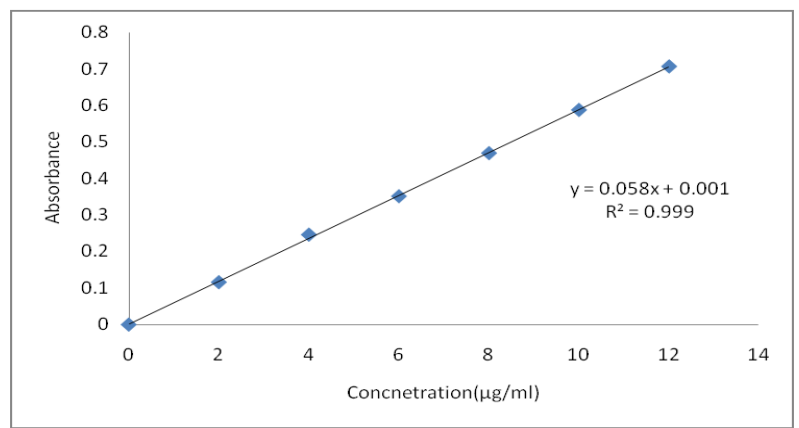

Fig 06: calibration curve of Luliconazole in $7.4 \mathrm{pH}$ buffer
Luliconazole beer's range concentration was found to be in the range of $2-12 \mu \mathrm{g} / \mathrm{ml}$ using $7.4 \mathrm{pH}$ buffer as buffer solution. The egression value was closer to 1 indicating the method obeyed Beer-lamberts' law as it was linear.

\section{Drug content}

The drug content was found to being the range of 95.12$99.36 \%$ for all the formulations indicating uniform distribution of drug.

Table 05: Drug content values of Luliconazoleemulgels

\begin{tabular}{|c|c|}
\hline Formulation code & Drug content \\
\hline F1 & 95.12 \\
\hline F2 & 96.45 \\
\hline F3 & 95.48 \\
\hline F4 & 97.24 \\
\hline F5 & 98.02 \\
\hline F6 & 99.13 \\
\hline F7 & 97.32 \\
\hline F8 & 95.43 \\
\hline F9 & 99.36 \\
\hline
\end{tabular}

\section{Discussion}

The percentage of drug content of formulation F1 was found to be $95.12 \%$, formulation F2 was found to be 96.45 $\%$, formulation F3 was found to be $95.48 \%$, formulation F4 was found to be $97.24 \%$, formulation $\mathrm{F} 5$ was found to be $98.02 \%$, formulation F6 was found to be $99.13 \%$, formulation F7 was found to be $97.32 \%$, formulation F8 was found to be $95.43 \%$, formulation F9 was found to 99.36\%

\section{pH Measurement}

Measurement of $\mathrm{pH}$ is very important for oral preparations measurement of $\mathrm{pH}$ is very important for oral preparations; otherwise it leads to irritation to the throat. All the formulation has a $\mathrm{pH}$ around neutral or slightly alkali. The $\mathrm{pH}$ of formulations was found in the range of $7.2-7.6$.

Table 06: pH values of Luliconazole Emulgels

\begin{tabular}{|c|c|}
\hline Formulation Code & pH \\
\hline F1 & 7.2 \\
\hline F2 & 7.4 \\
\hline F3 & 7.3 \\
\hline F4 & 7.5 \\
\hline F5 & 7.6 \\
\hline F6 & 7.3 \\
\hline F7 & 7.4 \\
\hline F8 & 7.5 \\
\hline F9 & 7.6 \\
\hline
\end{tabular}




\section{Discussion}

The $\mathrm{pH}$ of formulation $\mathrm{F} 1-\mathrm{F} 9$ was found to be in the range of $7.2-7.6$.

\section{Viscosity studies}

The formulation should have an optimum viscosity that will allow ease of administration and swallowing as a liquid and produces satisfactory gel strength for use as a delivery vehicle. The formulations showed a viscosity order of Carbopol940<HPMC $\mathrm{K} 15 \mathrm{M}<$ Xanthan gum. In addition to the influence of the type of viscosity enhancing polymer added, it was observed that increasing the concentration of the viscosity enhancing polymer in the formulation simultaneously increased the viscosity for all polymer types studied.

Table 07: Viscosity data of Luliconazole Emulgels (F1F9)

\begin{tabular}{|c|c|}
\hline Formulation Code & Viscosity(CPS) \\
\hline F1 & 146 \\
\hline F2 & 152 \\
\hline F3 & 158 \\
\hline F4 & 161 \\
\hline F5 & 169 \\
\hline F6 & 173 \\
\hline F7 & 178 \\
\hline F8 & 186 \\
\hline F9 & 195 \\
\hline
\end{tabular}

\section{Spreadability}

The spreadability of Carbopol based emulgel formulations $\&$ and of Xanthan gum based formulation is depicted intable. From the combined graph of all formulation it was concluded that all the developed formulation showed acceptable spreadability. Carbopolbased formulations showed better spreadability than HPMC K15M and Xanthan gum based.

Table 08: Spreadability of emulgel formulations

\begin{tabular}{|c|c|c|c|c|c|c|c|c|c|}
\hline $\begin{array}{l}\text { Formu } \\
\text { lations }\end{array}$ & $\begin{array}{l}\mathbf{F} \\
1\end{array}$ & 2 & 3 & 4 & 5 & 6 & 7 & 8 & $\begin{array}{l}\text { F } \\
9\end{array}$ \\
\hline $\begin{array}{l}\text { Spread } \\
\text { ability } \\
\text { (gm.cm } \\
\text { /sec.) }\end{array}$ & $\begin{array}{l}1 \\
9 . \\
4\end{array}$ & $\begin{array}{c}8 . \\
1\end{array}$ & $\begin{array}{l}1 \\
7 . \\
2\end{array}$ & $\begin{array}{l}1 \\
6 . \\
5\end{array}$ & $\begin{array}{l}1 \\
5 . \\
7\end{array}$ & $\begin{array}{l}1 \\
4 . \\
1\end{array}$ & $\begin{array}{l}1 \\
3 . \\
3\end{array}$ & $\begin{array}{l}1 \\
2 . \\
6\end{array}$ & $\begin{array}{l}1 \\
0 . \\
8\end{array}$ \\
\hline
\end{tabular}

\section{Invitro drug release study}

Table 09: Drug release data of Luliconazole emulgels (F1-F9)

\begin{tabular}{|c|c|c|c|c|c|c|c|c|c|}
\hline Time & F & F & F & F & F & F & F & F & F \\
(hrs) & $\mathbf{1}$ & $\mathbf{2}$ & $\mathbf{3}$ & $\mathbf{4}$ & $\mathbf{5}$ & $\mathbf{6}$ & $\mathbf{7}$ & $\mathbf{8}$ & $\mathbf{9}$ \\
\hline 0 & 0 & 0 & 0 & 0 & 0 & 0 & 0 & 0 & 0 \\
\hline
\end{tabular}

\begin{tabular}{|c|c|c|c|c|c|c|c|c|c|}
\hline \multirow{3}{*}{1} & 22 & 17 & 14 & 22 & 31 & 26 & 13 & 16 & 21 \\
\hline & .4 & .8 & .3 & .0 & .1 & .6 & .2 & .5 & .6 \\
\hline & 3 & 4 & 8 & 5 & 6 & 3 & 5 & 2 & 6 \\
\hline \multirow{3}{*}{2} & 34 & 28 & 25 & 31 & 40 & 37 & 19 & 25 & 31 \\
\hline & .2 & .3 & .3 & .2 & .7 & .4 & .6 & .0 & .1 \\
\hline & 5 & 1 & 6 & 4 & 5 & 2 & 2 & 6 & 3 \\
\hline \multirow{3}{*}{3} & 44 & 39 & 36 & 39 & 49 & 45 & 26 & 32 & 39 \\
\hline & .8 & .7 & .1 & .7 & .1 & .1 & .3 & .4 & .1 \\
\hline & 6 & 7 & 8 & 2 & 2 & 3 & 9 & 3 & 8 \\
\hline \multirow{3}{*}{4} & 55 & 50 & 47 & 48 & 57 & 53 & 33 & 39 & 45 \\
\hline & .4 & .9 & .5 & .1 & .7 & .0 & .4 & .7 & .5 \\
\hline & 5 & 8 & 9 & 9 & 6 & 8 & 6 & 5 & 9 \\
\hline \multirow{3}{*}{5} & 64 & 61 & 58 & 54 & 66 & 60 & 40 & 46 & 54 \\
\hline & .8 & .2 & .6 & .6 & .8 & .6 & .5 & .8 & .3 \\
\hline & 5 & 8 & 8 & 2 & 3 & 7 & 5 & 9 & 6 \\
\hline \multirow{3}{*}{6} & 76 & 73 & 69 & 61 & 75 & 69 & 47 & 54 & 63 \\
\hline & .9 & .2 & .5 & .7 & .5 & .1 & .8 & .0 & .1 \\
\hline & 6 & 6 & 6 & 3 & 2 & 3 & 3 & 6 & 3 \\
\hline \multirow{3}{*}{7} & 86 & 84 & 80 & 69 & 83 & 75 & 55 & 61 & 69 \\
\hline & .9 & .4 & .3 & .4 & .6 & .3 & .4 & .3 & .7 \\
\hline & 8 & 6 & 9 & 3 & 3 & 6 & 9 & 2 & 3 \\
\hline \multirow{3}{*}{8} & 98 & 94 & 88 & 82 & 91 & 81 & 62 & 68 & 74 \\
\hline & .8 & .7 & .7 & .3 & .8 & .4 & .4 & .7 & .5 \\
\hline & 7 & 1 & 6 & 6 & 6 & 1 & 2 & 8 & 3 \\
\hline \multirow{3}{*}{10} & & & 99 & 91 & 97 & 91 & 79 & 83 & 82 \\
\hline & & & .5 & .1 & .0 & .6 & .2 & .2 & .3 \\
\hline & & & 8 & 6 & 6 & 2 & 6 & 6 & 6 \\
\hline \multirow{3}{*}{12} & & & & & & 99 & 91 & 90 & 85 \\
\hline & & & & & & .1 & .0 & .3 & .8 \\
\hline & & & & & & 6 & 3 & 2 & 7 \\
\hline
\end{tabular}

\section{Invitro Dissolution Profile Graphs}

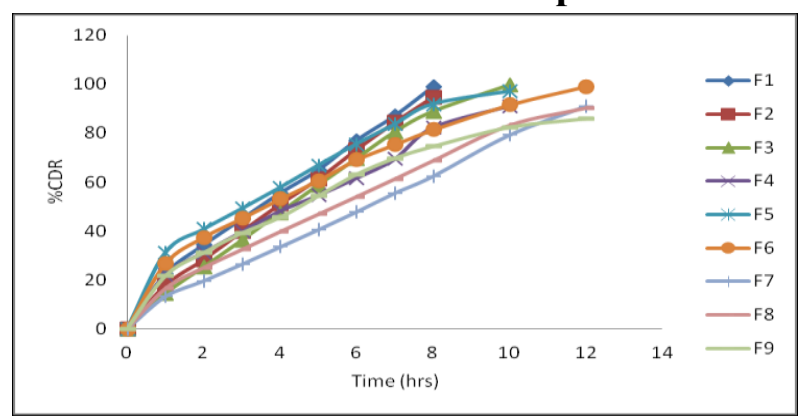

Fig 07: Invitro dissolution profile of F1-F9

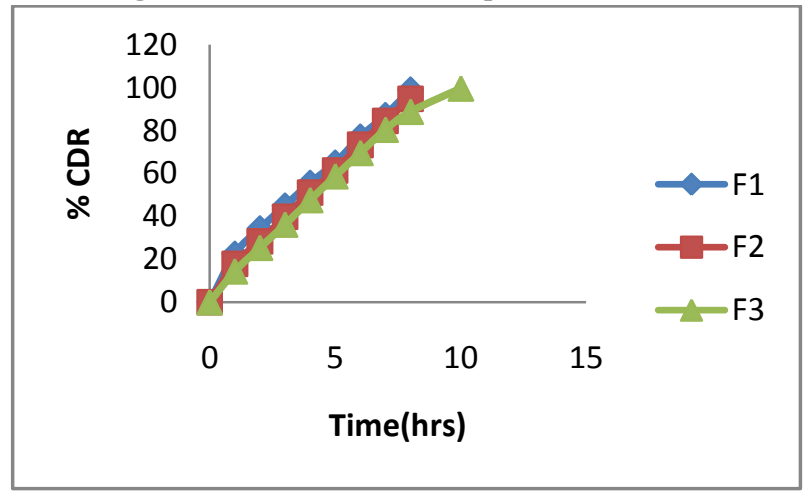

Fig 08: Invitro dissolution profile of F1-F3 
F1 formulation containing HPMC K15M shows $98.87 \%$ drug release at 8 Hours. where as F2 containing xanthan Gum shows $94.71 \%$ drug release at 8 hours, F3 containing Carbopol shows $99.58 \%$ drug release at 10 hours. so the concentrations of the polymers were further increased to get sustained release

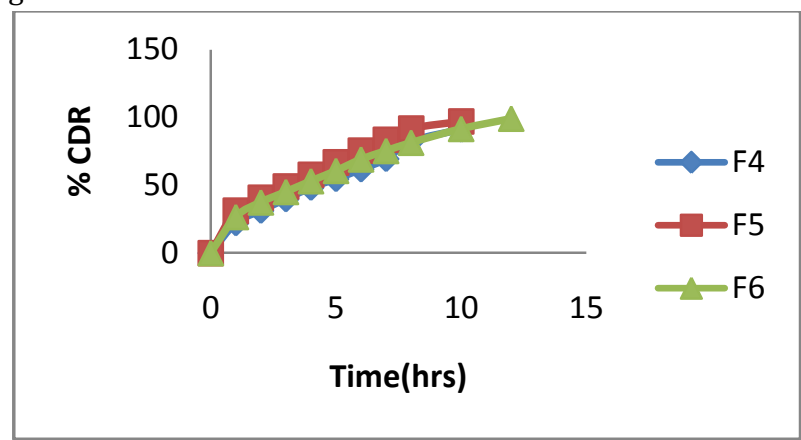

Fig 09: Invitro dissolution profile of F4-F6

F4 formulation containing HPMC K15M shows $91.16 \%$ drug release at 10 Hours, where as F5 containing Xanthan gum shows $97.06 \%$ drug release at 10 hours where as F6 containing carbopol shows $99.16 \%$ drug release at the end of 12 hrs.

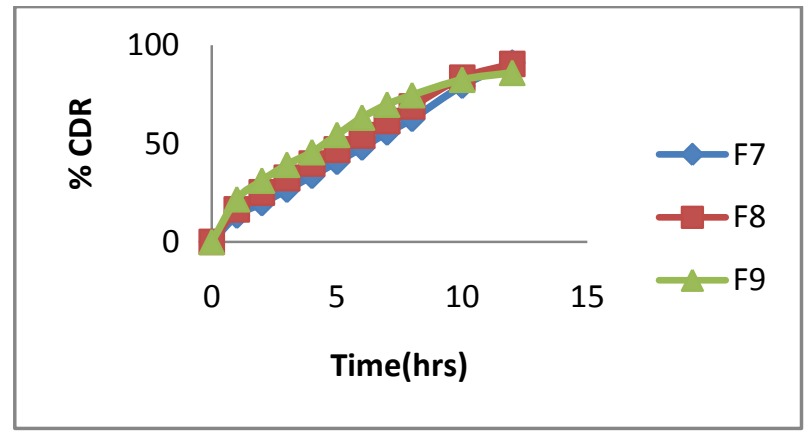

Fig 10: Invitro dissolution profile of F7-F9

F7 formulation containing HPMC K15 M shows 91.03\% drug release at 12 Hours but not in a sustained manner. where asF8 containing xanthan, gum shows $90.32 \%$ drug release at 12 hours but notin a sustained manner. Whereas F9 containing carbopolshows $85.87 \%$ drug release at the end of $12 \mathrm{hrs}$. So, formulation F6 is considered as the optimized formulation as it releases maximum amount of drug at the end of $12 \mathrm{hrs}$. Further drug release kinetics studies were performed for F6 formulation.

Drug Release Kinetic Studies

Zero Order Release Kinetics for formulation F6

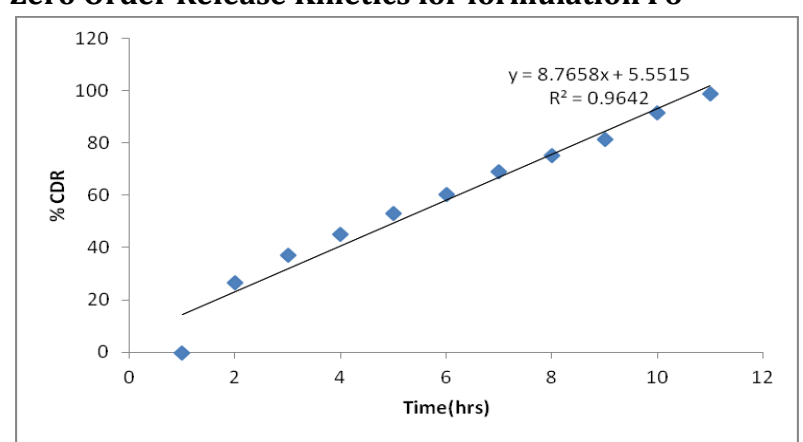

Fig 11: Zero Order Release Graph for F6

\section{First Order Release Kinetics For Formulation F6}

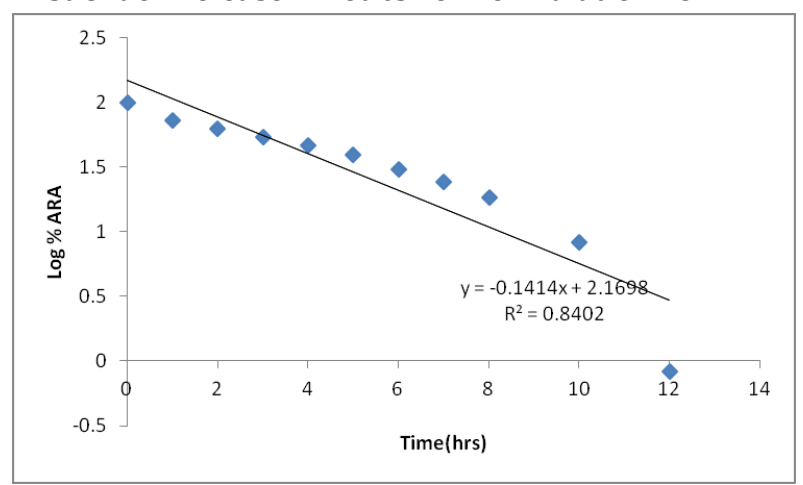

Fig 12: First Order Release Graph for F6 Higuchi Release Plot For Formulation F6

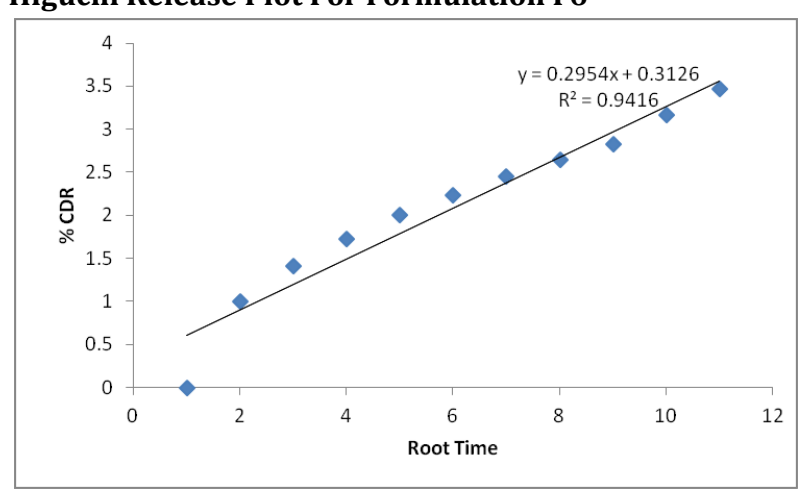

Fig 13: Higuchi Release Graph for F6

Peppas Release Plot For Formulation F6

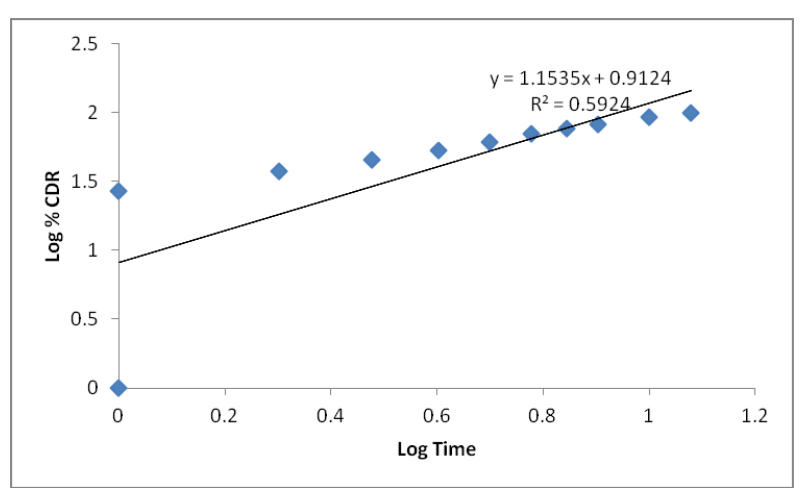

Fig 14: Peppas Release Graph for F6

Table 10: The release kinetics for the optimized formula F6

\begin{tabular}{|c|c|c|c|c|c|}
\hline \multicolumn{5}{|c|}{$\mathbf{R}^{2}$ values } & $\begin{array}{c}\mathbf{n} \\
\text { values }\end{array}$ \\
\hline $\begin{array}{c}\text { Formul } \\
\text { ation }\end{array}$ & $\begin{array}{c}\text { Zer } \\
\text { o } \\
\text { ord } \\
\text { er }\end{array}$ & $\begin{array}{c}\text { Fir } \\
\text { st } \\
\text { ord } \\
\text { er }\end{array}$ & $\begin{array}{c}\text { Higu } \\
\text { chi }\end{array}$ & $\begin{array}{c}\text { Korsm } \\
\text { eyer - } \\
\text { Peppa } \\
\text { s }\end{array}$ & $\begin{array}{c}\text { Korsm } \\
\text { eyer- } \\
\text { Peppas } \\
\text { (n) }\end{array}$ \\
\hline F6 & 0.9 & 0.8 & 0.94 & 0.592 & 1.153 \\
64 & 40 & 1 & & \\
\hline
\end{tabular}


The invitro dissolution data for best formulation F6were fitted in different kinetic models i.e, zero order, first order, Higuchi and korsemeyer-peppas equation. Optimized formulation $\mathrm{F} 6$ shows $\mathrm{R}^{2}$ value 0.964 . As its value nearer to the ' 1 ' it is conformed as it follows the Zero order release. The mechanism of drug release is further confirmed by the korsmeyer and peppas plot, if $\mathrm{n}=0.45$ it is called Case I or Fickian diffusion, $0.45<\mathrm{n}<0.89$ is for anomalous behaviour or non-Fickian transport, $n=0.89$ for case II transport and $n>0.89$ for Super case II transport. The ' $n$ ' value is 1.153 for the optimised formulation(F6) i.e., $n$ value was $>0.89$ this indicates case II super transport. The release kinetics for the optimized formula are shown in table. 10 .

\section{Summary and Conclusion}

Luliconazole is an antifungal medicine that fights certain infections caused by fungus. Luliconazole is used to prevent fungal infections in people who have a weak immune system resulting from certain treatments Luliconazole emulgels were prepared by using polymers like HPMCK15M, Xanthan gum, Carbopol 940, Tween 20, SPAN 20, Propylene glycol, Benzalkonium chloride, Methanol and water. (F1 to F9) formulations were prepared and F6 was found to be the best formulation. Drug and polymers was subjected for compatibility study using FTIR studies, which revealed that there was no interaction between drug and polymers. The prepared formulations were evaluated for drug content, $\mathrm{pH}$, viscosity, visual appearance $\&$ invitro release studies were also performed. The invitro release studies of all the formulations were discussed formulation $\mathbf{F 1}$ formulation containing HPMC K15M shows $98.87 \%$ drug release at 8 Hours. where as F2 containing xanthan Gum shows 94.71 $\%$ drug release at 8 hours, F3 containing Carbopol shows 99.58\% drug release at 10hours. F4 formulation containing HPMC K15M shows $91.16 \%$ drug release at 12 Hours, where as F5 containing Xanthan gum shows 97.06 $\%$ drug release at 10 hours where as F6 containing carbopol shows $99.16 \%$ drug release at the end of $12 \mathrm{hrs}$. F7 formulation containing HPMC K15 M shows $91.03 \%$ drug release at 12 Hours but not in a sustained manner. where as F8 containing xanthan gum shows $90.32 \%$ drug release at 12 hours but not in a sustained manner. Where as F9 containing carbopol shows $85.87 \%$ drug release at the end of $12 \mathrm{hrs}$.

Optimized formulation F6 has 99.16\% drug release. since the formulation containing coarbopol with highest concentration shows drug release in a sustained manner whereas the other polymers didn't show sustained release. So, the F6 formulation was considered as the optimized formulation. So the drug release kinetics were performed for the optimized formulation. The release kinetics of the optimized formulation was best fitted into Higuchi model $\left(\mathrm{R}^{2}=\mathbf{0 . 9 4 1}\right)$ and showed zero order $\left(R^{2}=\mathbf{0 . 9 6 4}\right)$ drug release with super case II mechanism. From the above experimental results it can be concluded that, Luliconazole was chosen as the model candidate for development of emulgels, since they possess near ideal characteristics that these drugs must have formulating sustained drug delivery system.

The results of study demonstrate that carbopol 940 was suitable to develop sustained release emulgels.

\section{References}

1. Lawrence HB. Medicated Topicals. Ch.44 in Remington. In: Lippincott Williams and Wilkins. Editors the science and practice of pharmacy 21th ed. Philadelphia; 2006.

2. Mohamed MI. Topical emulsion- gel composition comprising Diclofenac sodium. AAPS Journal, 6(3), 2004.

3. Mohamed MI. Optimization of chlorphenesin emulgel formulation. AAPS Journal, 6(26), 2004.

4. Rieger MM, Lachman L, Lieberman HA. Editors. The theory and the practice of industrial pharmacy 3rd ed. Philadelphia; 1986.

5. Shahin M, Abdel HS, Hammad M, Mortada N. Drug development and industrial pharmacy,37(5):559-568, 2011. 6. British Pharmacopoeia. Appendix ID: A 143(4), 2008.

6. Andressa da S. Bitencourt; Sendy S. Oliveira; Andreas S. L. Mendez; Cássia V. Garcia. UV Spectrophotometric method for determination of posaconazole: comparison to HPLC. Rev Ciênc Farm Básica Apl., 2015;36(4):491-495.

7. Potu A, Pasunooti S, Veerareddy P, Burra S. Formulation \& Evaluation of Fenoprofen calcium compressed coated tablets for Colon Speeific Drug Delvery. Asian Journal Pharmaceuticals clinical Research 2011; 4:88-95.

8. Karrout Y, Neut C, Wils D, Siepmann F, Deremaux L, Siepmann J. Novel PolymereFilm Coating for Colon Targeting Drug Release From Coated Pellets. European Journal of Pharmaceutical Sciences 2009; 37:427-433.

9. Ugurlu T, Turkoglu M, Gurer US, Akarsu BG. Colonic Delivery of Compression Coated Nisin tablets using Pectin/HPMC Polymer mixture. European Journal of Pharmaceutics And Biopharmaceutics 2007; 67:202-210.

10. Lakshmi KR, Muzib YI, Voleti VK. Design and Evaluation of colon specific drug delivery of Naproxen sodium using Guar gum and Crosslinced Guar Gum. International Journal of Pharmacy and pharmaceutical sciences. 2012; 4:284-288

11. Kirankumar GB, Naresh YS, Mohammed GA, Abdul NK. Design and Evaluation of a new capsule type dosage form for colon Targeted delivery of Etoricoxib. International Journal of Pharma Sciences 2013; 3: 147-151.

12. Verma S, Singh SK, Mishra DN, Gupta A, sharma R. formulation and evaluation of microbially 
triggered tablet of valdecoxib International Journal of Drug delivery Technology 2009;1: 611.

13. Ramasany T, Khandasamy US, Shanmugan S, Ruttala HA. Formulation and Evaluation of chondroitin sulphate tablets of Aceclofenac for colon Targeted Drug delivery. International Journal of Pharmaceutical Research 2012; 11: 465-479.

14. GB K, Annangi V, Ahamed M, Kumar G. Preparation and evaluation of kollidon SR matrix Tablets of Tinidazole for colon specific drug delivery . International Journal of science Invents today 2013; 2:97-106.

15. Krishnaiah YSR, Satyanarayana V, Kumar BD, Karthikeyan RS. In-vitro drug release studies on guar gum-based colon targeted oral drug delivery system of 5-fluorouracil European Journal of pharmaceutical of 2012;16: 185-192.

16. Shailaja D, Kumar MS, Gnana Chaitanya NK. Formulation \& Evaluation of Colon Specific Compression coated tablets of Etodolac International Journal of Pharma World Research 2012; 3:1-16.

17. Higuchi T. Mechanism of sustained action medication. Theoretical analysis of rate release ofsolid drugs dispersed in solid matrices. J. Pharm Sci. 1963; 52(12): 1145-9.

18. Korsmeyer RW, Gurny R, Doelker E, Buri P, Peppas NA. Mechanisms of solute release from porous hydrophilic polymers. Int J Pharm.1983; 15(1): 25-35.

19. Marabathuni VJ, Dinesh P, Ravikumar R, Yamini P, Kiran PS, Hussain SP, Rao CM. Chitosan based sustained release mucoadhesive buccal patches containing amlodipine besylate (AMB). Asian J Res Pharm Sci. 2017 Jun 28;7:97-104.

20. V Jhansipriya Marabathuni, M. Bhavani, M. Lavanya, K. Padmaja, N. Madhavi, P. Babu, Ch. M. M. Prasada Rao. Formulation and evaluation of mouth dissolving Tablets of carbamazepine. Asian J. Pharm. Tech. 2017; 7 (3): 137-143 